\title{
On numerical investigation of stability of roadbeds reinforced by gabion structures
}

\author{
Farkhadjan Adilov ${ }^{1}$, and Rustam Abirov ${ }^{2 *}$ \\ ${ }^{1}$ Institute of mechanics and earthquake engineering, 100125, Tashkent, Uzbekistan \\ ${ }^{2}$ AKFA University, Tashkent, Uzbekistan
}

\begin{abstract}
The stability of roadbed in seismic prone areas is vital for the sustainable economic development of regions. The gabion structures are one of the methods of road strengthening. Gabion structures are used to avoid damage to the roadbed under loads of natural ground slope due to earthquake or other reasons. This approach is one of the most economical and efficient solutions for the stabilization of natural ground slopes, and it is efficient as a drainage system. Field tests give precise results about the efficiency of gabion types for different sites. However, in some cases, it is expensive and numerical calculation can be used for the estimation of the applicability of gabions. The stability of roadbed by using finite element approaches was investigated here. Stability was considered as results of calculations by two cases with gabions and without ones were compared. The dynamic and seismic impact was taken into account according to local normative documents.
\end{abstract}

\section{Introduction}

Slopes of embankments, excavations and roads made of water-absorbing clay soils are often destroyed. The reasons might make a steep fall of a mountain valley or the presence of loose weathering products in the upper reaches of the valley within the drainage area due to heavy rainfall. In the calculation of soil stability problems, constitutive relations have great importance. Thus different types of research on slope stability and the development of stabilization methods are wide provided [1-5].

Nowadays the green technologies are mainstream in the world. Plant succession as the effect on slope stability is described as an ecological approach [6, 7]. The porosity of gabions may also sum up favorable effects on the near shore environment [8]. However, in the general case, these models and rules are not applied in building codes yet and not included in the software.

In flood prone areas, the stability of earth structures is a vital element for the region's sustainable development. Gabion may help against erosion processes there [9] because gabions act on the piers and abutments during flooding. Experimental studies on the hydraulics of flow through and over gabion-stepped weirs are investigated. The energy loss ratios in the gabion-stepped weirs are greater than those in the corresponding horizontal stepped weirs [10].

* Corresponding author: rustam_abirov@mail.ru 
Also, gabion weirs can be offered as an alternative design that could be adopted for flash flood mitigation. A series of laboratory experiments were performed [11] in order to investigate the flow over gabion weirs. Moreover, gabions are one of the most economically and overall efficient solutions [12] to stabilise natural ground slopes.

Below is the approach close to engineering methods based on the finite element technique applied here. Mechanical characteristics of soil and filling materials were experimentally determined, the dynamic and seismic coefficient was used for the specified site.

Nowadays, for roadbed in seismic prone areas, wide spectra of strengthening measures are used and also, in some cases, gabions are used too. Uzbekistan local building codes for road structures do not have special approaches for calculating the stability of structures yet. Only in several cases, field tests were provided. Our goal is to propose the method of calculation of roadbed, strengthened by gabions.

\section{Methods}

A numerical approach for analysis of deformation behaviours of single gabion under uniaxial compression was proposed and considered in this work [13]. There is a multibody of modelling of stone-filled gabions described and investigated [14]. In this work, the results show that the discretized multibody modelling can be effectively used for the description of static deformation behaviour of gabion blocks. Numerical and experimental investigations of new gabion barrier prototype in the mountain area (Nepal) and the seismic prone zone were evaluated [15].

Slope stability on mountain area without gabion strengthening in many cases can also be provided by other measures [16, 17]. However, in rainfall or seismic prone areas for a long road operating in some sites, it is vital. Therefore, such approaches are investigated in this issue.

\subsection{Primary calculation}

Therefore, it is necessary to carry out calculations of the external and internal stability of the gabion wall with a stepped front face (fig.1), located on the left side of a section of the highway of category II (ordinary road). The wall consists of box-shaped gabions $1 \mathrm{~m}$ high, made of mesh with a wire diameter of $3.0 \mathrm{~mm}$. The specific weight of the filling stone material of the gabion structure is $\gamma_{s}=26 \mathrm{kN} / \mathrm{m}^{3}$; the porosity is $n=0.30$. The roadbed soil is a loam with an estimated angle of internal friction $\varphi=30^{\circ}$, cohesion $\mathrm{c}=8 \mathrm{kPa}$, a specific weight $\gamma=18.9 \mathrm{kN} / \mathrm{m}^{3}$ and a strain modulus of $30 \mathrm{MPa}$. The width of the gabion wall base is $B=2 \mathrm{~m}$. 

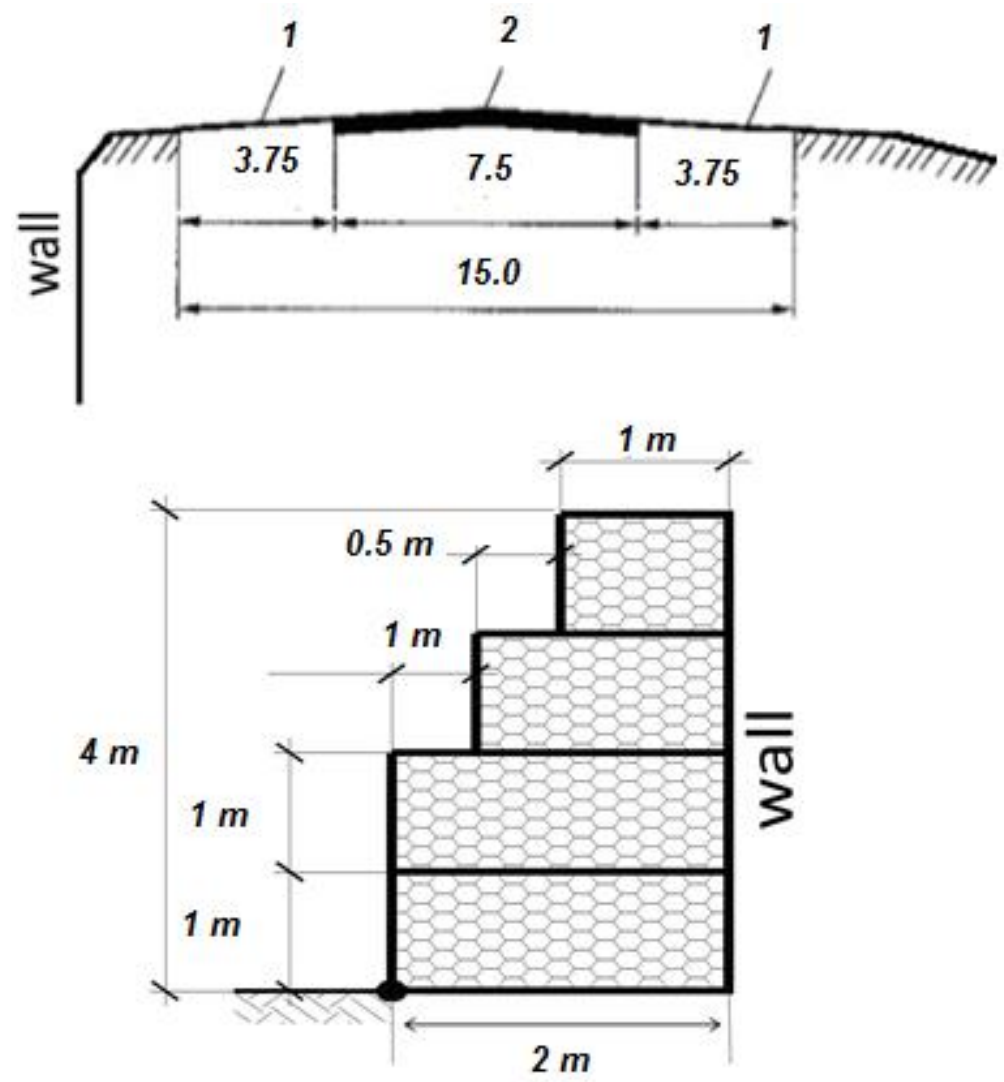

Fig. 1. Section of a road of category II and a gabion wall: 1 is roadsides, 2 is roadbed.

The specific weight of the gabion structures of the retaining wall is determined by the next formula:

$$
\gamma_{g}=\gamma_{S} \cdot(1-n)=26 \cdot(1-0.30)=18.2 \mathrm{kN} / \mathrm{M}^{3}
$$

According to state standards (GOST R 51285-99), the friction angle and specific cohesion of gabion structures on the calculated surface are determined by the formulas:

$$
\begin{gathered}
f_{g}=2.54 g_{g}-10=2.5418 .2-10=35.5^{0} \\
c_{g}=3 \cdot P_{u}-5=3 \cdot 8.55-5=20.65 \mathrm{kPa}
\end{gathered}
$$

Here the strain modulus of gabions is $420 \mathrm{MPa}$. The strength problem was solved by using the finite element approach $\left(\mathrm{N}_{\mathrm{el}}=867, \mathrm{~N}_{\text {node }}=884\right)$. The boundary conditions are specified as follows: along the vertical boundaries of the accepted model, there are no displacements in a horizontal direction; there are no vertical displacements along the lower horizontal border; no restrictions are imposed on the displacements of other points.

When strength calculating the slope of the road, the load on the single, most loaded axle of a biaxial vehicle with a frame of $130 \mathrm{kN}$ is taken into account and the weight of the pavement and own weight of the roadbed and gabions. At the same time, we will take into 
account the least favorable position of the transport load in an emergency stop on the side of the road.

According to the developed methods, the external load from traffic is multiplied by a dynamic coefficient equal in the range of $\mu=1.1-1.2$, the estimated seismicity of the area is 9 points, seismicity coefficient is $\mathrm{k}_{\mathrm{c}}=0.1$.

In the first case, the calculations were performed to assess the stability of the vertical slope by taking into account the effect of external load. Figure 2 shows the corresponding values for a given area, which can be used to estimate the stress state of this array. Figure 3 shows graphical data on the stability state of vertical slope. However, the slope does not have a sufficient margin of stability, and as a consequence, it must be strengthened by gabion structures.

Nowadays, different types of gabions are using. Our choice was the simplest type of such structure and available by local engineering skills in this approach.
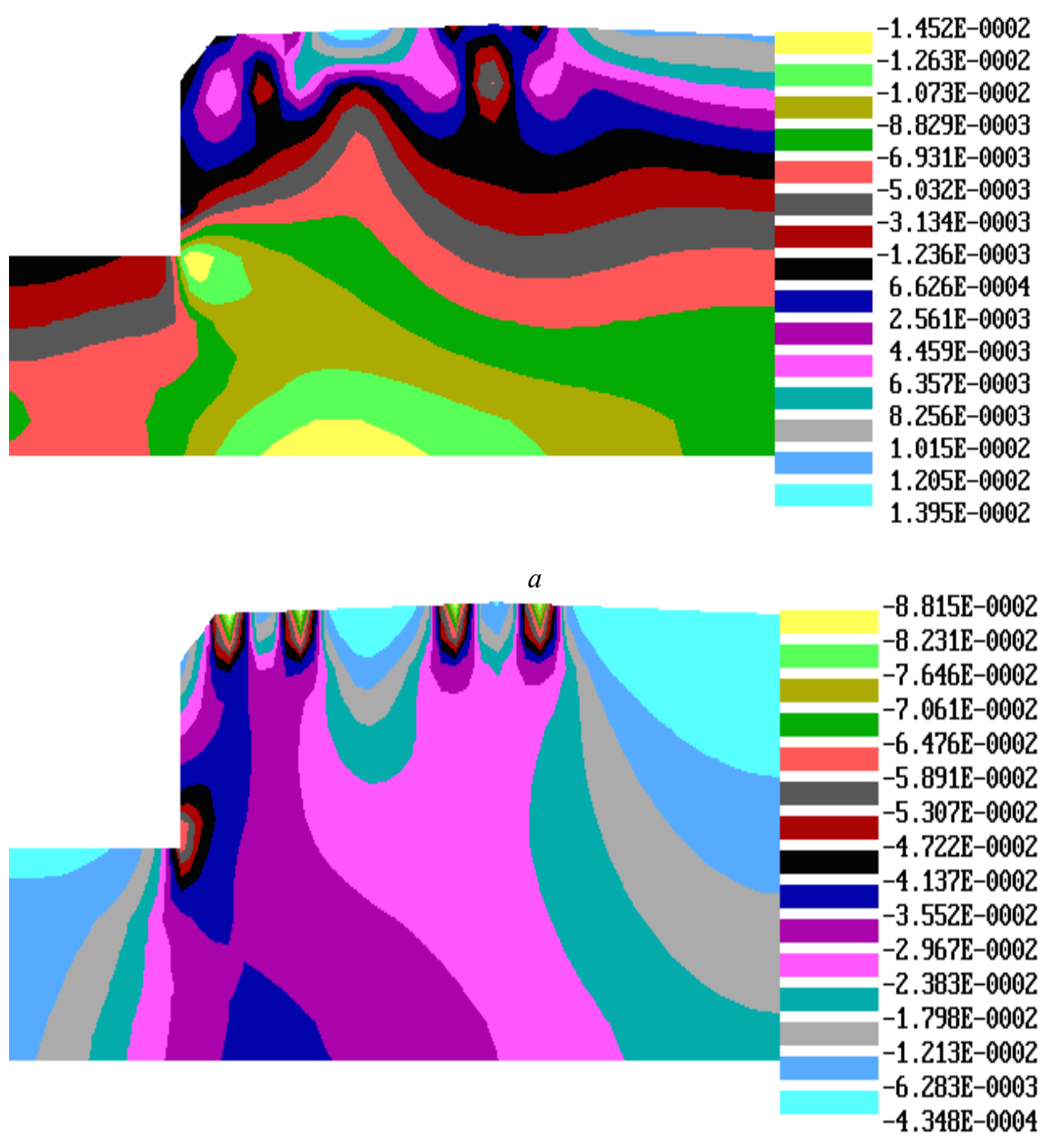

$b$

Fig. 2. Principal stresses, Mpa: a is maximal principal stresses, $b$ is minimal principal stresses 

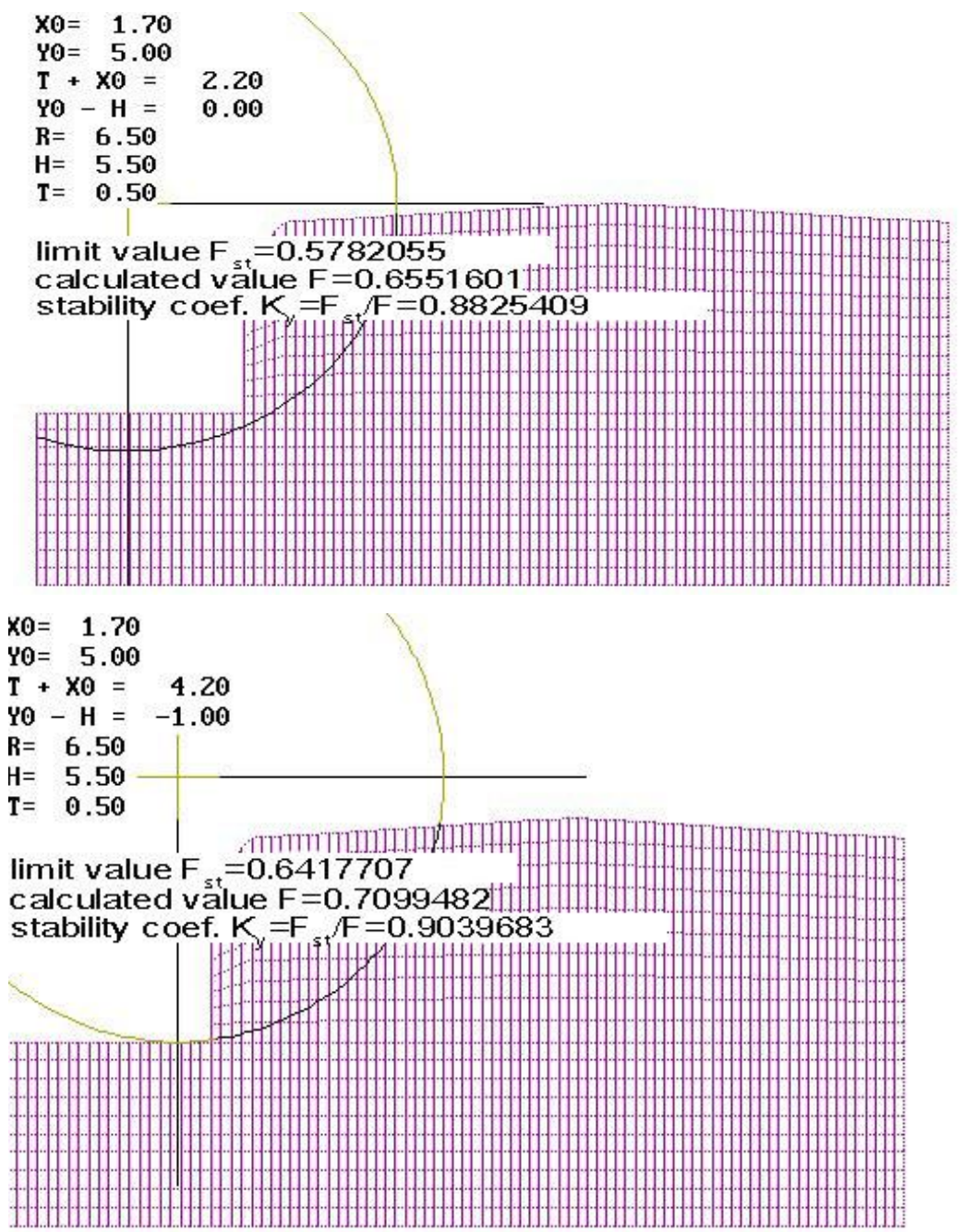

$\begin{array}{ll}\mathrm{X} O=1.70 & \\ Y 0=5.00 & \\ \mathrm{~T}+\mathrm{X} 0= & 2.20 \\ Y 0-H= & 0.00 \\ \mathrm{R}=6.50 & \\ H=5.50 & \\ \mathrm{~T}=0.50 & \end{array}$

limit value $F_{s t}=0.9610608$

Calculated value $F=0.83924911$

stability coef. $K=F_{\varepsilon t} / F=1.145144$

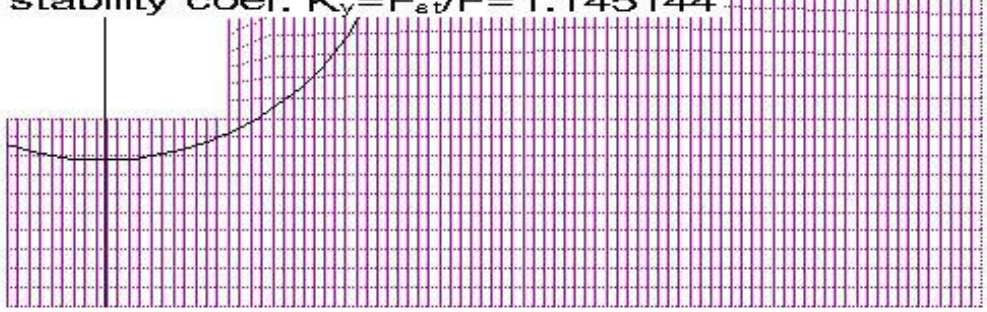

Fig. 3. Calculated stability coefficients of the slope 


\section{Results and Discussion}

Let us consider calculation with gabion structure. Consider a section located between $3^{\text {rd }}$ and $4^{\text {th }}$ layers of a gabion wall (fig.4). The wall width in this section is $B_{i}=2 \mathrm{~m}$. The normal stresses acting on the contact of this layer are determined by the formula:

$$
\sigma_{i}=\frac{\sum G_{g i}}{B_{i}}=\frac{(18.2+27.3+36.4) \cdot 10^{3}}{2}=0.04095 \mathrm{MPa}
$$

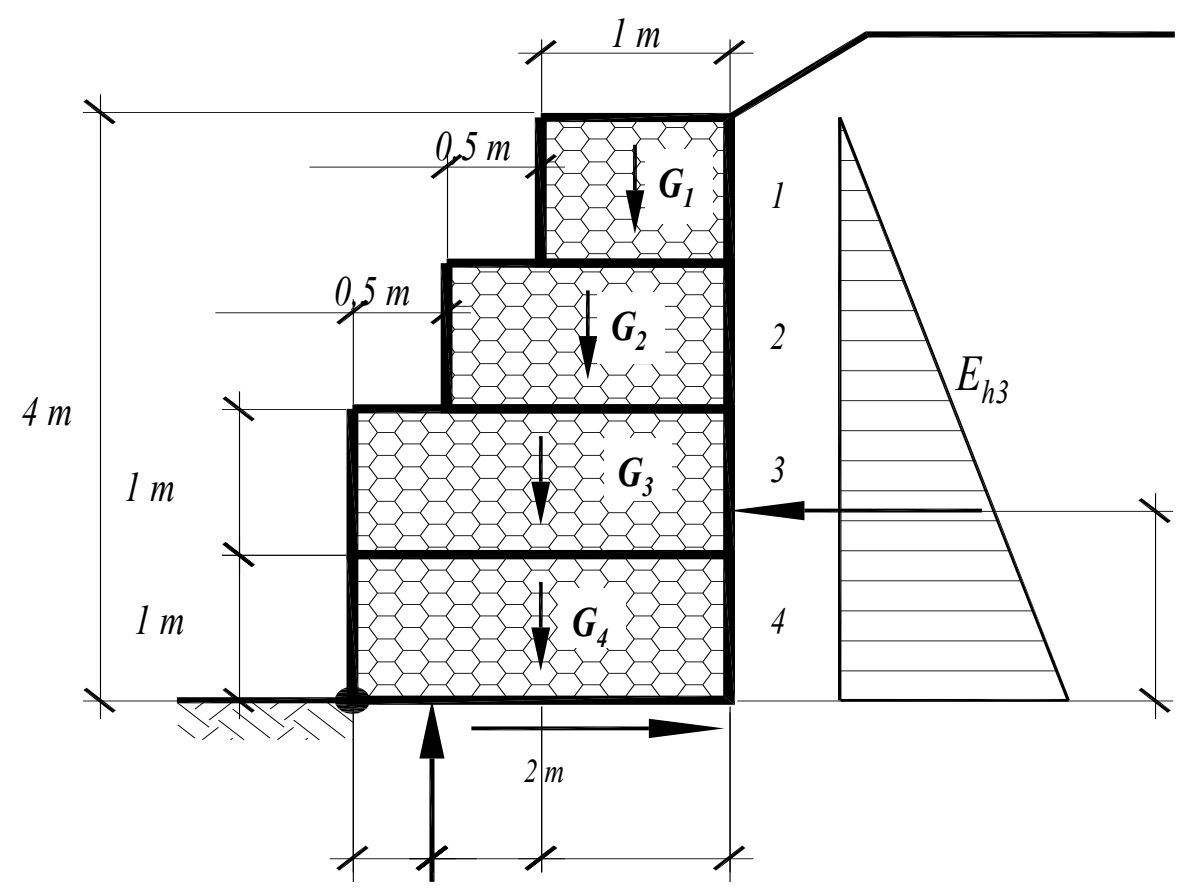

Fig. 4. Design scheme to calculate the internal stability of massive-volume gabion wall.

The value of permissible normal stresses on gabion structures is determined at a safety factor of $\mathrm{k}_{\mathrm{g}}=1.15$ according to the formula:

$$
\left[\sigma_{g}\right]=\frac{50 \cdot \gamma_{g}-300}{k_{g}}=\frac{(50 \cdot 18.2-300) \cdot 10^{3}}{1.15}=0.53043 \mathrm{MPa}
$$

The strength of the gabion structure under normal stresses is checked under the condition:

$$
\left[\sigma_{g}\right]=0.53043 \mathrm{MPa} \geq \sigma_{i}=0.04095 \mathrm{MPa}
$$




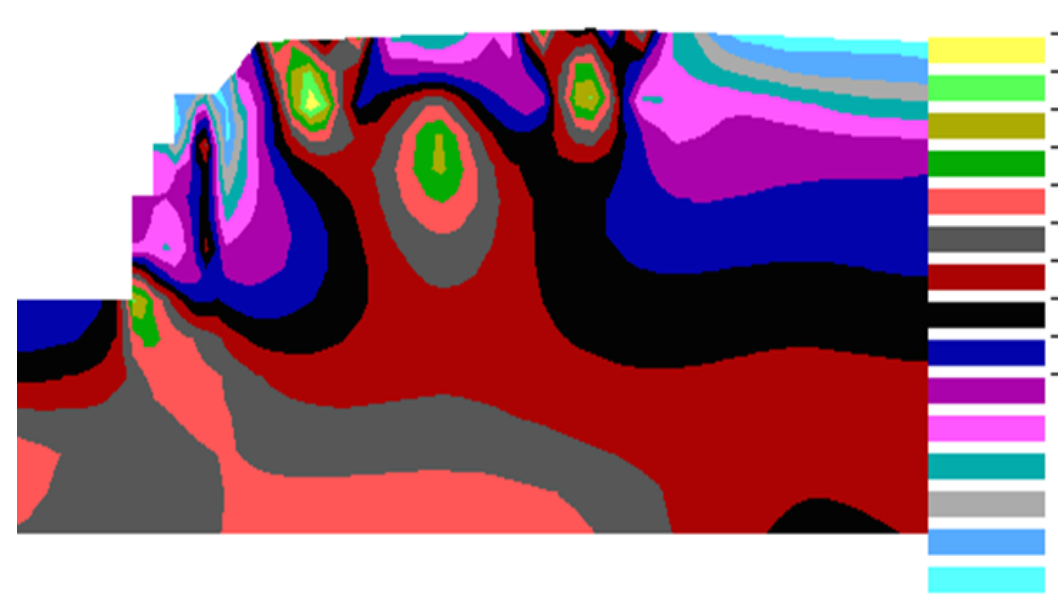

$-9.244 \mathrm{E}-0003$

$-8.218 \mathrm{E}-0003$

$-7.191 \mathrm{E}-0003$

$-6.165 \mathrm{E}-0003$

$-5.138 \mathrm{E}-0003$

$-4.112 \mathrm{E}-0003$

$-3.085 \mathrm{E}-0003$

$-2.059 \mathrm{E}-0003$

$-1.032 \mathrm{E}-0003$

$-5.771 \mathrm{E}-0006$

$1.021 \mathrm{E}-0003$

$2.047 \mathrm{E}-0003$

$3.074 \mathrm{E}-0003$

$4.100 \mathrm{E}-0003$

$5.127 \mathrm{E}-0003$

$6.153 \mathrm{E}-0003$

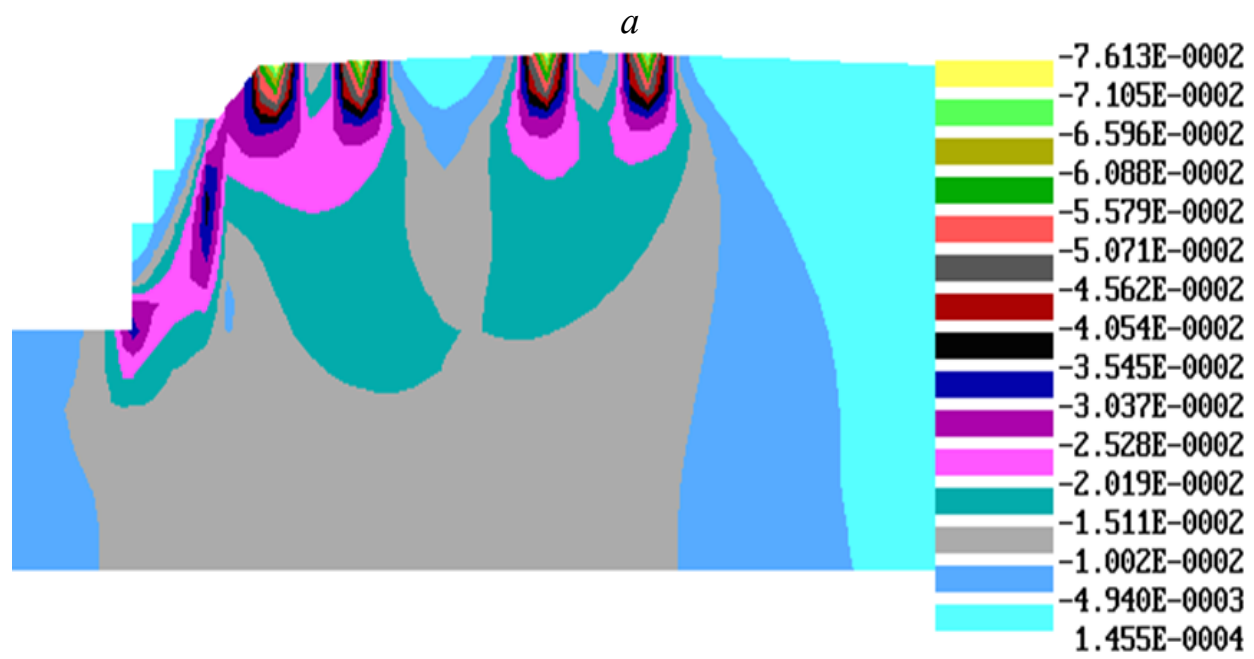

$b$

Fig. 5. Maximal and minimal principal stresses, MPa: a is maximal principal stresses, $b$ is minimal principal stresses.

Therefore, the strength stability of the gabion structure of the retaining wall in the considered section is sufficient. The strength of the remaining gabion structures is calculated similarly. Consider the same section between $3^{\text {rd }}$ and $4^{\text {th }}$ layers of the gabion wall. The magnitude of the horizontal shear force in the considered section is $E_{h i}=$ $0.02531 \mathrm{MPa}$.

The acting tangential stresses are determined by the formula:

$$
\tau_{i}=\frac{E_{h i}}{B_{i}}=\frac{0.02531}{2}=0.01266 \mathrm{MPa}
$$

Figure 5 presented the stress values pattern for the calculated area with taking into account the gabion structure. Figure 3 shows graphical data on the stability state of a vertical slope with gabion strengthening. 

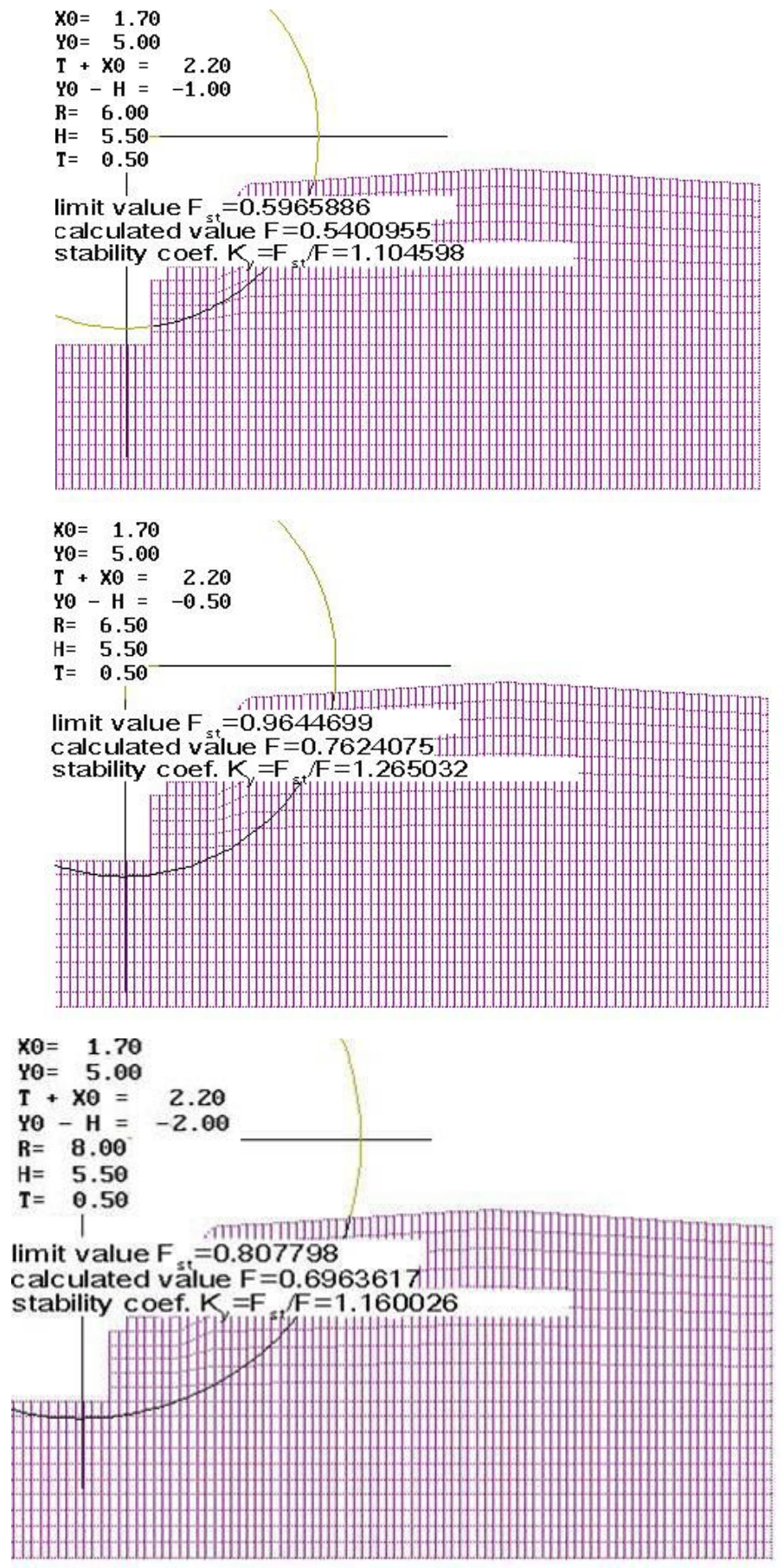

Fig. 6. Calculated coefficients of stability of the slope

The mass of the mesh of a box-shaped gabion structure in the considered section made of mesh with a wire diameter of $3.0 \mathrm{~mm}$, according to the International branch road codes "MODN 2-2001". The allowable value of tangential stresses is determined with a safety factor of $k_{g}=1.15$ according to the formula: 


$$
\left[\tau_{g i}\right]=\frac{\sigma_{i} \cdot \operatorname{tg} \phi_{g}+c_{g}}{k_{g}}=\frac{0.04095 \cdot \operatorname{tg} 35.5^{0}+0.0205}{1.15}=0.04336 \mathrm{MPa}
$$

The possibility of shear of individual layers of the gabion wall is checked from the condition:

$$
\left[\tau_{g i}\right]=0.04336 M P a \geq \tau_{i}=0.01266 M P a
$$

In this study, a numerical approach to simulate the mechanical behaviour of roadbed under seismic loading was proposed. In site, field test can arise other loads as well as humidity influence, etc. This study is the first stage for stress strain analysis of roadbed strengthening by gabions. In each case, in situ tests have to be provided by considering numerical results as a preliminary approach.

\section{Conclusions}

Based on analysis of calculations, the influence of basic parameters of gabions on road stability provided, its deformability was also investigated. Numerical results have shown that the use of gabions significantly increases the strength of the road. By numerical analysis, the gabion structures lead to a significant strengthening of the existing roadbed and can be applied in loess soils. According to these theoretical investigations and comparisons with field tests results, the approach will be proposed for new building codes concerning road structures.

\section{References}

1. Duncan M, Wright S and Brandon T Soils Strenght and Slope Stability (Wiley) p. 272 (2014)

2. Abramson Lee W., Thomas S. Lee, Sunil Sharma, Glenn M. Boyce 2001 Slope Stability and Stabilization Methods (Wiley) p. 736, (2001)

3. Sagdullayeva D A, Maxmudova Sh A, Adilov F F, Abirov R A, Khazratkulov I O and Nasirov I A J. Phys.: Conf. Ser. 1425 (2020) https://doi:10.1088/17426596/1425/1/012016

4. Adilov F, Miralimov M and Abirov R IOP Conf.Ser.: Mater. Sci. Eng. p.913 (2020) https://doi: 10.1088/1757-899X/913/4/042066

5. Gu M, Collin J G, Han J, Zhang Z, Tanyu B F, Leshchinsky D, Ling H I and Rimoldi $\mathrm{P}$ Numerical analysis of instrumented mechanically stabilized gabion walls with large vertical reinforcement spacing Geotext. Geomembranes (2017) https://doi: 10.1016/j.geotexmem.2017.04.002

6. Osman N and Barakbah S S Ecol. Eng. 37(2) 139-147 (2011) https://doi: 10.1016/j.ecoleng.2010.08.002

7. Kortiev A L, Vaneev C D and Dryaev M M 2020 Sustain. Dev. Mt. Territ. https://doi: 10.21177/1998-4502-2020-12-1-55-60

8. Srineash V K and Murali K Procedia Engineering 116 552-559 (2015) https://doi: 10.1016/j.proeng.2015.08.325

9. Ramli M, Karasu T J R and Dawood E T Alexandria Eng. J. 52(4) 705-710 (2013) https://doi.org/10.1016/j.aej.2013.07.005

10. Chinnarasri C, Donjadee S and Israngkura U J. Hydraul. Eng. 134(8) (2008) 
https://doi: 10.1061/(ASCE)0733-9429(2008)134:8(1147)

11. Mohamed H I 2010 J. Irrig. Drain. Eng. 136(8) pp. 573-577 https://doi: 10.1061/(asce)ir.1943-4774.0000215

12. Toprak B, Sevim O and Kalkan I Int. J. Adv. Mech. Civ. Eng. 3(4) pp. 56-58 (2016)

13. Lin D, Huang B and Lin S Proc. INTERPRAEVENT (Taipei) (2010) https://doi: 10.1016/j.proeng.2016.08.466

14. Amato G, O’Brien F, Simms C K and Ghosh B 2013 Int. J. Crashworthiness 18(3) pp. 237-250 https://doi: 10.1080/13588265.2013.775739

15. Amato G, O’Brien F, Ghosh B and Simms C 2015 Int. J. Crashworthiness 20(1) pp. 12-26 https://doi: 10.1080/13588265.2014.949038

16. Bogomolov A, Ponomaryov A and Bogomolova O ICSMGE 2017 - 19th International Conference on Soil Mechanics and Geotechnical Engineering (2017)

17. Grishina A S and Ponomaryov A B 2016 Analysis of efficiency of fiber reinforced sand as a backfill of retaining walls Challenges and Innovations in Geotechnics Proceedings of the 8th Asian Young Geotechnical Engineers Conference, 8AYGEC (2016) 